\title{
Applying ERRC of Blue Ocean Strategy: A Value Innovation for Contracting Carrier Company Study Case in Indonesia
}

\author{
Ahmad Sugiono', Agus Rahayu', Lili Adi Wibowo ${ }^{1}$ \\ 1 Indonesian Education University, Bandung, West Java, Indonesia
}

\begin{abstract}
This study aims to determine the strategy's ability to make price competition irrelevant and optimize the company's operating costs. This type of research uses descriptive qualitative research with the subject of this research is one of the Freight Forwarding companies in Jakarta, namely IGL. The results obtained in this study, among others, by creating partners abroad (Key Partnership), which focus on having freehand shipments import and nominee shipments export, can make a condition where price competition becomes irrelevant. The results also show that focusing on being a contractual carrier and procurement of warehouses is also proven to positively impact operational costs and company performance, provide added value to customers, and support the company's main business.
\end{abstract}

Keywords: Blue Ocean Strategy, Contractual Carrier, Logistic

This is an open access article under the CC-BY-NC license

\section{INTRODUCTION}

Competition in the Freight Forwarding market in Indonesia has been increasingly severe because many new companies entered Indonesia. An increasingly dynamic and complex competition has occurred in the business world and is increasingly being accelerated by Covid-19. Garry, Hamel and C.K. Prahalad. (1994) observe that competition is getting more challenging, and business commoditization increases. The national logistics industry continued to grow during the global crisis in 2008 even though many industry players stopped production, resulting in a decrease in demand for logistics needs, including delivery (Utaminingsih, 2011). The Indonesian Logistics Association (2020) revealed that it turned out that only the e-commerce logistics sector achieved 18.1\% growth during the Covid 19 pandemic. However, in total, the industry was still below $10 \%$, so that as of the end of the third quarter of 2020 , the logistics sector was still minus value (Dinda, 2020). The Indonesian freight and logistics market was valued at USD 81.30 billion in 2020, and it is expected to reach more than USD 135 billion by 2026, registering a growth rate of more than $7 \%$ during the forecast period. Indonesia has been severely affected by the COVID-19 crisis. The lack of a centralized and adequate government response has led to uncoordinated responses, including a lockdown on Jakarta and business-as-usual in mines and the agricultural sector. According to the Indonesian Logistics Association (ALI), logistics companies have experienced an approximately 50\% decline in overall business performance since the COVID-19 outbreak hit Indonesia in early March 2020. It is reported that logistics volume has been down by $60-70 \%$ across the board due to emergency measures taken by the government to prevent COVID-19 transmission.

After COVID-19, as the industry positions itself to recover and grow, technology will increasingly play an important role, enabling all stakeholders, including shippers, operators, warehouse owners, and 
Journal of Governance Risk Management Compliance and Sustainability (JGRCS), Vol. 1 (1), 18-27

Applying ERRC of Blue Ocean Strategy: A Value Innovation for Contracting Carrier Company Study Case in Indonesia

Ahmad Sugiono, Agus Rahayu, Lili Adi Wibowo

suppliers, to effectively respond to changing market realities. At the core of domestic and international trade, uncertainty remains a significant problem in Indonesia's supply chain. The uniqueness of the archipelago of 17,000 islands exacerbates tension, meaning that who cannot truck it well inland.

Logistics using land transportation services are still the mainstay of the transportation service industry. Road transportation accounts for $70-80 \%$ of the total transportation handled in Indonesia each year. Regarding value, the land transportation market share still accounts for $40-50 \%$ of the overall logistics market. The shipping industry plays a vital role in Indonesia's trade because $90 \%$ of Indonesia's exports are transported by water. Shipping companies face operational problems, such as low port efficiency, which results in increased waiting and settlement times, and the risk of labor disputes.

This condition makes logistics companies need a concept that can make the company out of the competitive map. One of these concepts is the Blue Ocean Strategy Concept, which creates a market space with no competitors. The word competition becomes irrelevant because the company focuses on growing demand and moving away from competition (Kim and Mauborgne, 2017).

Previous research has researched and produced a Blue Ocean Strategy, whereby doing work steps that are principled on the blue ocean, they can generate ideas and value innovation and greatly assist companies in marketing strategies and company strategic steps (Fauzan \& Jayanti, 2015; Hamijaya \& Indriyani, 2014; Melinda, 2018; Susanto, 2018; Utaminingsih, 2017). The research results by Utaminingsih (2011), whose research uses a sample of integrated logistics companies, show that increasing networks and creating vendor management, and increasing safety can create a new value curve and provide suggestions for automation to increase the value curve to customers. Other logistics companies have not carried out technology applications such as RFID. They have also proven to increase the company's competitive advantage when transitioning to the blue ocean so that competition becomes irrelevant (Changsu Kim, Kyung HoonYang, Jaekyung Kim 2008). The combination of Lean Manufacturing with Blue Ocean strategy by mapping the value flow and the framework of the four Blue Ocean actions and the framework implemented in the selected case studies were able to provide a reduction in waiting time and value-added time of $26 \%$ and 39\%, respectively (Sadiq, Amjad, et al. Rafiq et al. 2019). However, research related to the blue ocean strategy in logistics companies that focus on a contractual carrier has not been carried out by previous researchers, so it is interesting to do research.

The purpose of this study is to find out whether the strategy used can make price competition irrelevant and whether the strategy used by the company can optimize operational costs? The expected contributions from the results of this research include: (1) Can be used as a reference when conducting studies or research that is strategic, (2) Knowing that there are new and innovative alternative strategies in the Forwarding industry can create companies that continue to grow and have high performance and ability to provide a strong brand image in the minds of buyers.

\section{LITERATURE REVIEW}

Kim and Maurbogne (1997) argue that a focus on benchmarking and winning the competition will lead to an imitative, not innovative, approach to markets that often results in price pressures and further commoditization. So companies should try to make competition irrelevant by offering a jump in value to buyers, namely the company's ability to avoid competition and re-conceptualize the existing industry model (Garry Hamel, 1998). not against the competition. Competitive strategy is divided into cost leadership, differentiation (differentiation), and focus strategy (Porter, 1980). 
In the field of business strategy, an overcrowded market is often referred to as the "Red Sea," and business here is full of the blood of competitive warfare (Kim \& Mauborgone (2005). According to Kim and Mauborgone (2005), the key to moving away from overcrowded spaces relates to what they call "strategic initiatives." Critical to this is the concept of "value innovation, " emphasizing the importance of the same two words value and innovation. Kim and Mauborgone (2005) observe that simply emphasizing innovation without delivering appropriate value is unhelpful. If customers don't understand the value they provide, technology-centric products often confuse customers-technology goes beyond what buyers are willing to pay. Or, creating value without innovation will only cut costs while providing little or no meaningful value to customers. The price war is one sign for the Red Ocean was the current situation.

According to Kim and Mauborgne (2005), a blue ocean strategy is a company strategy to get out of the red ocean by creating a blue ocean, namely by value innovation that combines innovation with benefits, prices, and cost positions. Value innovation rejects one of the most common dogmas used in competitionbased strategies: the dilemma or value-cost trade-off. So that blue ocean strategy can help achieve excellence in a fast and efficient way. This strategy is not limited to executive orders only, and managerial staff can also implement and reap its rewards (Loh et al., 2018). So the Blue Ocean strategy also helps in practical implementations such as improving logistics processes (Kim etal., 2008). The profile of a strategy that has high potential will have complementary qualities (Kim and Mauborgne, 2005), as follows: 1. Focus, the company, does not spread its efforts to all the main factors in the competition. 2. Divergence, away from other players, a result of looking and looking for alternatives and not from comparing from competitors. 3. Attractive motto, a good motto should not only be able to convey a clear message but also advertise the offer or product honestly.

\section{RESEARCH METHOD}

\section{Type Research}

This research is company strategy content research conducted descriptive qualitatively to explore the meaning of a social problem (Creswell, 2012). The study was conducted based on the blue ocean strategy in 2020 at one of the logistics companies in Jakarta, namely IGL. The company was chosen because its business disclosure authority is one of the most accessible for researchers in disclosing business facts during the study.

\section{Method of collecting data}

Primary data are interviews conducted in this study, namely to key parties or experts in IGL itself (internal), key parties or experts outside the company (external), along parties from ALFI (Indonesian Logistics and Forwarder Association). The results of the interviews are used as identification of competitive factors as the basis for making strategy canvases. In addition, supporting data for secondary data are company-internal data and various literature such as articles and books.

\section{Data Analysis and Presentation Method}

The stages in the qualitative data analysis used were adapted from the opinions of Miles, Huberman, and Saldana (2014), namely data collection, data condensation, data presentation, and verification and conclusions. All data will be analysed and interpreted to obtain facts that occurred and conclusions that answer the objectives of this study. The framework for making Strategic Blue Ocean is as follows: 
Journal of Governance Risk Management Compliance and Sustainability (JGRCS), Vol. 1 (1), 18-27

Applying ERRC of Blue Ocean Strategy: A Value Innovation for Contracting Carrier Company Study Case in Indonesia

Ahmad Sugiono, Agus Rahayu, Lili Adi Wibowo

1. Identify Alternative Industries

At this stage, identify company opportunities in other lines or alternative industries.

2. Identify Alternative Strategic Groups

At this stage, it is done by observing the strategic group. This term refers to companies in an industry pursuing a common strategy. Strategic groups, in general, can be ranked in a rough hierarchical order built on two dimensions, namely price and performance.

3. Identify Alternative Buyer Groups

At this stage, the chain of buyers (purchasers and users) of the company's services is examined.

4. Identification of Alternative Products and Services

This stage will look at the core offerings for the company's products and services. Then identify alternative products and services that the company can do.

5. Identify Alternative Industry Attractive Orientations

At this stage, the industry's attractiveness from a functional and emotional point of view is examined. Approach and education by human resources 6 . Identify Industry Trends This stage looks at the industry trends that occur.

The steps for the Blue Ocean Strategy (Kim and Mauborgne, 2005) used are as follows:

1. Formulation of the Strategy Canvas the strategy canvas will show a visual analysis of how an organization forms its offer to buyers, compared to competitors' offerings, where essential elements of the strategy will be shown, which includes what factors are up for grabs, the level of offers that buyers receive, strategy profiles and cost structures. The current strategy canvas is a self-assessment from the team's point of view, which will then be made in two dimensions, represented by a horizontal axis (a range of factors that are used as a competition and industry investment) and a vertical axis (the level of supply received by buyers as the main competency factor).

2. Formulation of the Four-Step Framework and ERRC Scheme There are several steps, namely: a. Eliminate (eliminate), Factors that are considered standard and taken for granted by the industry will be eliminated because they no longer have value or even reduce value. b. Reduce; investment in factors that do not provide increased benefits to buyers to industry standards. c. Raise investment in competitive factors that provide a significant increase in benefits for buyers to industry standards will be increased $d$. Create (create), By creating new factors that have never been offered in the industry, the company provides unique value benefits for consumers or nonconsumers to achieve new demand.

\section{Research Analysis and Framework}

The analysis stage (figure 1) is adapted from Miles. et al. (2014) and Kim and Mauborgne (2005) will start from the reconstruction process of existing market boundaries until finally getting a series of Blue Ocean strategies. 
Journal of Governance Risk Management Compliance and Sustainability (JGRCS), Vol. 1 (1), 18-27

Applying ERRC of Blue Ocean Strategy: A Value Innovation for Contracting Carrier Company Study Case in Indonesia

Ahmad Sugiono, Agus Rahayu, Lili Adi Wibowo

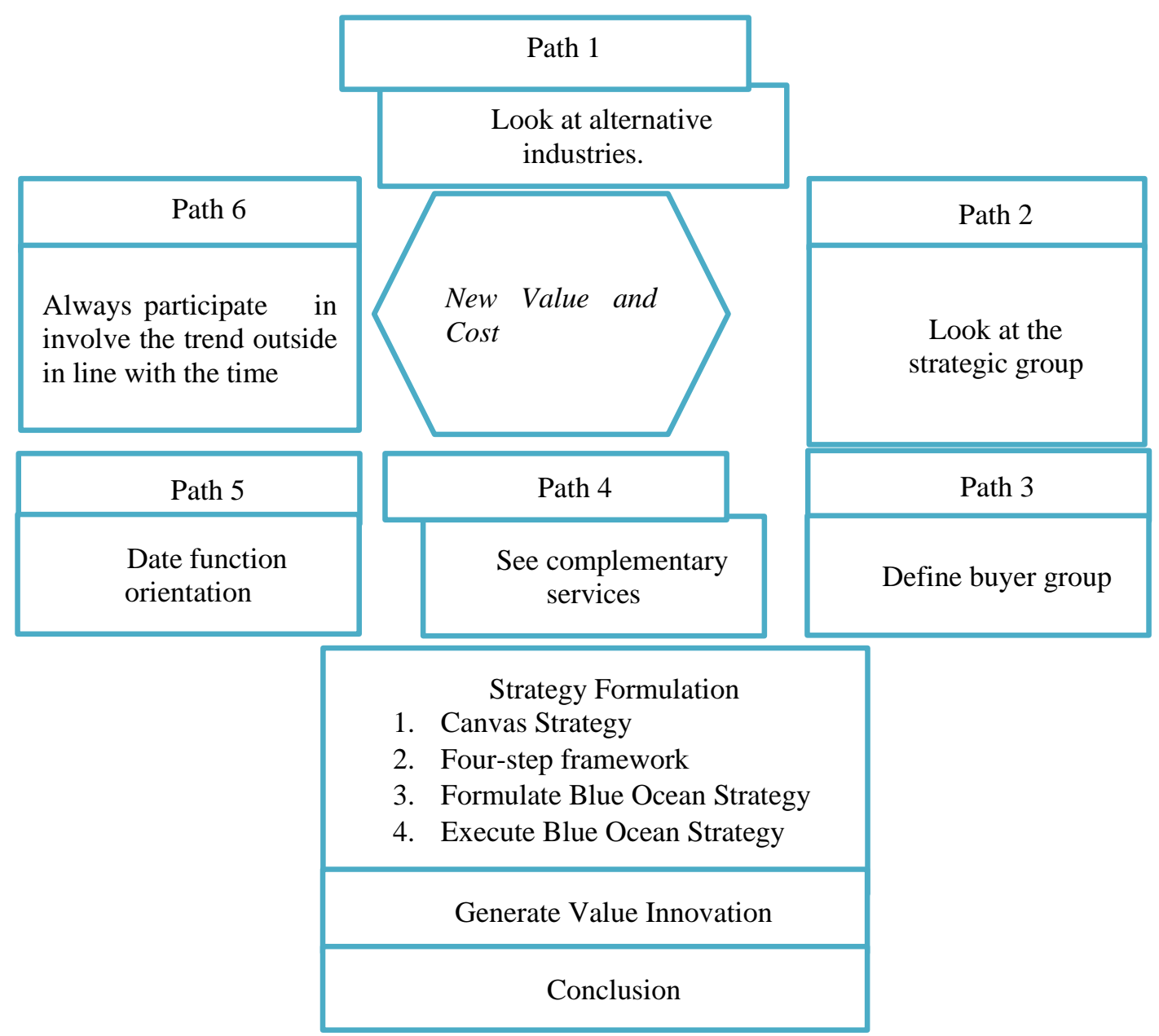

Figure 1. Research Framework

\section{FINDINGS AND DISCUSSION}

\section{Six Strategic Blue Ocean Frameworks}

\section{Identify Alternative Industries}

IGL is a Freight Forwarding company whose scope of business is the management and delivery of export and import goods and focuses on services for the category of small goods that are consolidated into one container or to a unit device and simultaneously sent when space is filled. Logistics service business activities are essentially inclusive from the starting point to the endpoint and are adapted to the resources owned by each company. IGL, with its limited financial resources, chooses to collaborate with other license holders (Under name) as an alternative business so that it takes a different form but has the same goal, namely the delivery of goods with complete export and import documents. Another alternative is to invest in the Indonesia Stock Exchange in transportation and warehousing issuers. Although they are different in form and function, they have the same goal of making money flow through the logistics sector. 
Journal of Governance Risk Management Compliance and Sustainability (JGRCS), Vol. 1 (1), 18-27

Applying ERRC of Blue Ocean Strategy: A Value Innovation for Contracting Carrier Company Study Case in Indonesia

Ahmad Sugiono, Agus Rahayu, Lili Adi Wibowo

\section{Identification of Alternative Strategic Groups}

IGL, which focuses on activities as a contractual carrier, can be classified as a partial service with minor integrated service. The main focus for targeting customers is to make the best use of selecting the right Incoterm group from the transporter side for both export and import activities.

\section{Identification of Alternative Buyer Groups}

At this stage, the chain of buyers (purchaser and user) of IGL is a Freight Forwarding company that focuses on purchasers and users as a chain of buyers. Both concerning services have a role that is not much different. The purchaser here is positioned as part of the export-import company as the base customer. In contrast, the user is set as a company engaged in the same field but entrusts part of the goods to be sent to a particular destination point.

\section{Identification of Alternative Products and Services}

At this stage, it can be observed that the complementary product and service offerings of IGL as a player in the Freight Forwarding industry. In the delivery of export and import goods to ensure that the goods can be received in good condition, insurance is essential. On the other hand, importers are reluctant to take care of their administration to insurance companies. Utilizes this opportunity-IGL in providing alternative services to its customers. In addition, under name services for exporters and importers who do not have permits are also another alternative that can be provided.

\section{Identification of Alternative Industry Attractive Orientations}

Approach and education by human resources at IGL, with experience and international certification in logistics, is consistently able to provide convenience in transactions and become a loyal customer.

\section{Steps for Blue Ocean Strategy Activities}

Strategy Canvas Formulation

\begin{tabular}{|c|l|c|c|}
\hline No & \multicolumn{1}{|c|}{ Competency factor } & IGL & Competitor \\
\hline 1. & Price & 0.72 & 0.54 \\
\hline 2. & Information and technology & 0.48 & 0.64 \\
\hline 3. & Safety & 0.60 & 0.80 \\
\hline 4. & Customs broker & 0.45 & 0.45 \\
\hline 5. & Human resource & 0.48 & 0.64 \\
\hline 6. & Overbrengen speed & 0.60 & 0.45 \\
\hline
\end{tabular}

Table 1. Comparison of Competition Factors of IGL with Competitors

In table 1 can be described the condition of the competence of IGL with current competitors. We can explain the value curve that forms the basis of the strategy canvas that explains its situation related to its competencies (figure 2). 
Journal of Governance Risk Management Compliance and Sustainability (JGRCS), Vol. 1 (1), 18-27

Applying ERRC of Blue Ocean Strategy: A Value Innovation for Contracting Carrier Company Study Case in Indonesia

Ahmad Sugiono, Agus Rahayu, Lili Adi Wibowo

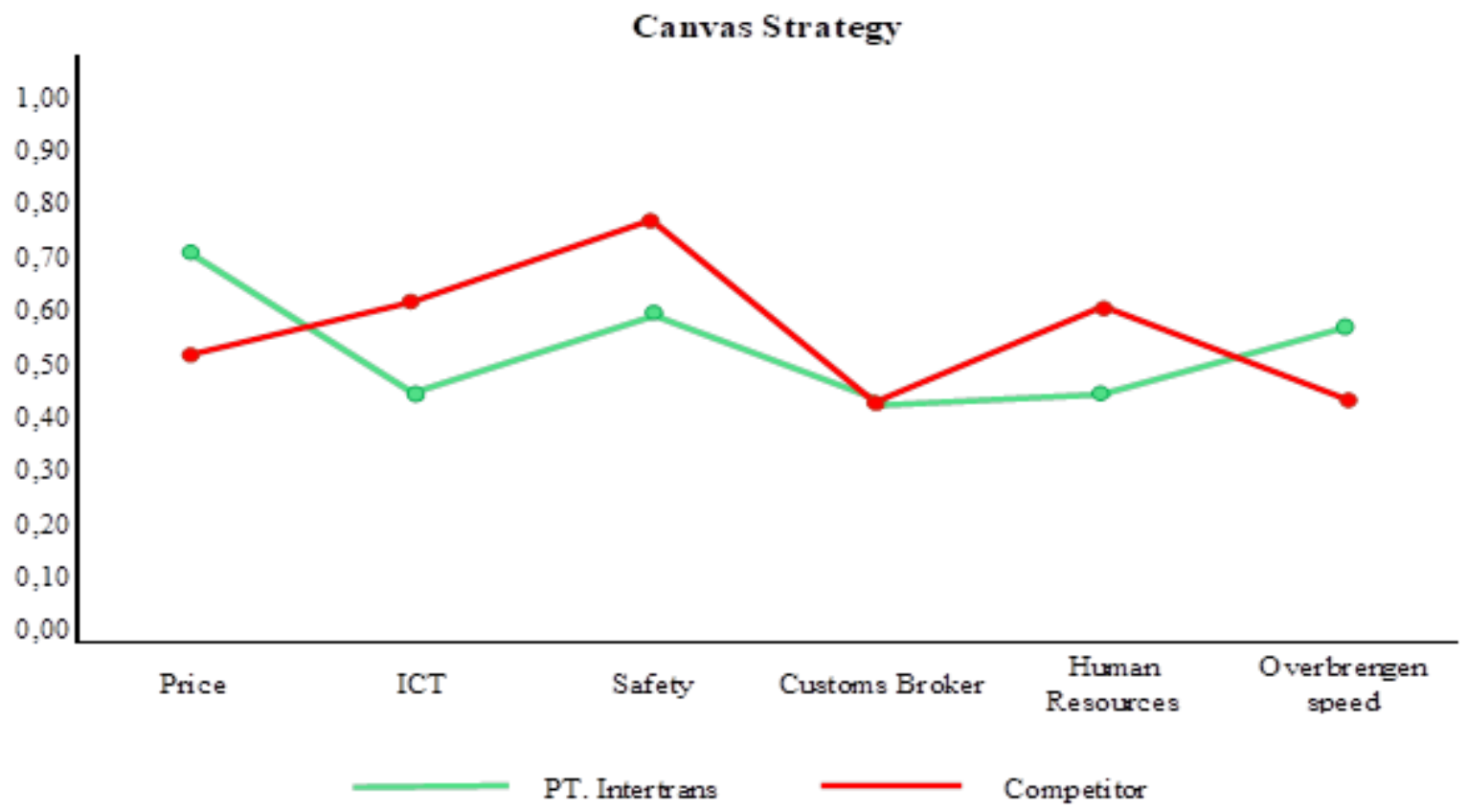

Figure 2. Canvas Strategy

From Figure 2, it can describe that the two value curves of IGL and competitors tend to have the same basic form. It shows that the strategies they are currently pursuing grow to be homogeneous but with different offering levels. It can describe an exchange between the costs incurred and the value obtained by the customer (Trade-off). IGL with lower tariffs offers advantages on other factors, while the opposite happens to other companies, namely applying higher prices but having key factors below IGL.

Formulation of the Four-Step Framework and ERRC Scheme

The four-step framework at IGL consists of:

1. Factors that must eliminate: customs brokers.

2. Factors to reduce: price and speed overbrengen.

3. Factors that must be improved: Information technology, security, and competence of human resources.

4. Factors that must create: Agency and Warehousing.

The steps above can describe in the strategy canvas (picture 3), which has a new value and is the Blue Ocean. 


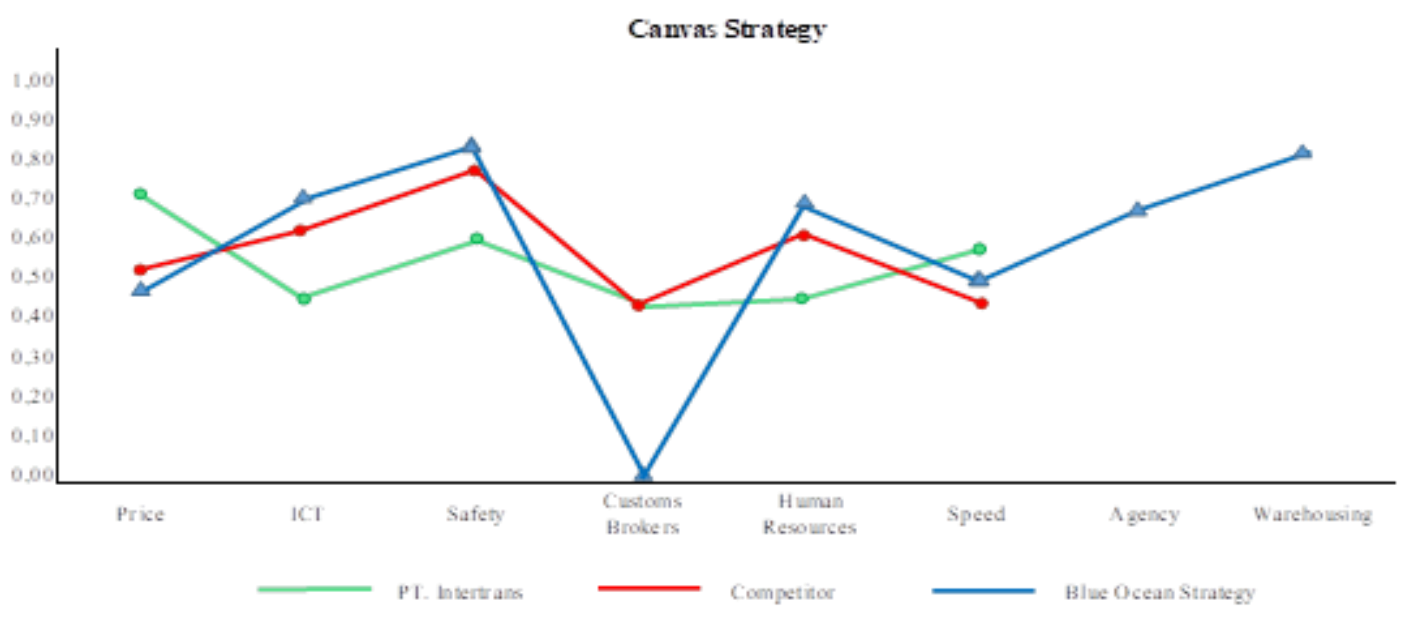

Figure 3. Canvas Strategy

Based on Figure 3, it can see that there is a difference with Figure 2; this is due to the addition and reduction of activities in the company. Blue ocean strategy adopts a unique thing because value and cost can go hand in hand to optimize existing resources and focus on their primary business, namely as a contractual carrier.

ERRC Scheme at IGL can be briefly described in the following table.

\begin{tabular}{|c|c|}
\hline $\begin{array}{l}\text { Eliminate } \\
\qquad \quad \text { Customs Brokers service }\end{array}$ & $\begin{aligned} \text { Raise } & \\
\bullet & \text { ICT } \\
\bullet & \text { Safety } \\
\bullet & \text { Human Resources }\end{aligned}$ \\
\hline $\begin{array}{l}\text { Reduce } \\
\qquad \text { Price } \\
\text { • Speed of Overbrengen }\end{array}$ & 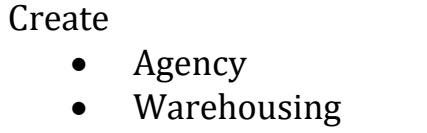 \\
\hline
\end{tabular}

Table 2. ERRC Scheme at IGL

\section{Strategy Formulation}

Identify a series of strategies IGL are as follows:

1. Eliminate and reduce

At this strategic stage, IGL abolished Customs Brokers service because their activities required a high cost and risk but only provided insignificant benefits. By focusing on becoming a contractual carrier, the cost allocation can be optimized and capture other more prospective opportunities with more controlled risks. In addition, prices also need attention because customer profiling is relatively insensitive to price changes as long as the services provided are good and the security of the goods is maintained.

2. Improve and create

At this strategic stage, IGL improves information technology, human resources, and goods security. Along with technological developments in the current 4.0 era wherein the logistics sector uses blockchain and platform-based has stated before, it is necessary to develop human resources. Currently, the National Logistics Ecosystem will be launched and requires logistics sector players to participate in the platform. Investments in information technology are made so that they not only follow trends but are also able to 
create independent platforms that are integrated with government platforms. In addition, investment in technology and information will increase the level of security of goods. In contrast, in the warehouse, and until the goods are sent through tracing and tracking activities.

From the Blue Ocean strategy theory, that focus is one thing that has high blue ocean potential for this IGL focuses on services as a contractual carrier and leaves the customs service business. This issue is possible because the customs service business requires high operational costs for bailouts for importers, extended payment terms, and increased risk. By focusing on becoming a contractual carrier, it will be able to reduce costs and be allocated to strengthen other sectors, namely warehousing. Warehousing is significant in supporting activities as a contractual carrier and being able to reduce costs incurred. Another thing that creates was the agency's collaboration with partners abroad, especially those with their cargo (freehand shipment import and nominated shipment export). With the incoterm clause, it is possible to get the order from an attractive and aggressive agent in the market to increase market expansion and reduce existing price competition.

\section{CONCLUSION \& FURTHER RESEARCH}

\section{Conclusion}

results of the analysis and discussion that have been carried out, can be concluded as follows: Focus

In this Focus strategy, not all logistics services are carried out but focus on the core business, namely as a contractual carrier.

\section{Divergence}

Divergence is a movement away from competitors. It offers things that competitors do not offer. In this case, the company carries out various activities that add a competitive advantage, such as:

1. Creating agents abroad who have their cargo (increasing the number of freehand shipments imported and increasing export nominations from partners abroad.

2. Concentrate on warehousing to support the main business as a contractual carrier to reduce other costs that arise.

Motto

a good strategy has a clear and compelling motto. IGL is committed to becoming the largest professional International Freight Forwarding and Consolidator known for its friendly, fast, safe and flexible service with a network spread throughout the world. IGL has a motto that is The Right Partner for Your Business.

\section{Research Limitations}

This study only applies to one company. Further research is recommended to conduct research on other companies. This study can be used to help companies find ways to compete and avoid red oceans. It also contributes scientifically to the blue ocean strategy.

\section{Suggestions}

Based on the conclusions that have been stated above, then on this occasion, the author tries to provide suggestions as follows:

1. With a focus on the core business, namely as a contractual carrier, it can improve services and add new customers, both cargo owned by itself and owned by partners from abroad. 
Journal of Governance Risk Management Compliance and Sustainability (JGRCS), Vol. 1 (1), 18-27

Applying ERRC of Blue Ocean Strategy: A Value Innovation for Contracting Carrier Company Study Case in Indonesia

Ahmad Sugiono, Agus Rahayu, Lili Adi Wibowo

2. So that IGL can offer contractual carrier services to non-customers so far, namely other freight forwarding companies, to become Master Consolidators with a larger market share.

3. With the motto "The Right Partner for Your Business," IGL can continue to improve the services provided to customers through the values approach developed through the ERRC process.

\section{ACKNOWLEDGMENT}

The researcher would like to thank the leaders and staff of IGL for the opportunity and willingness to help during this research.

\section{REFERENCES}

Asosiasi Logistik Indonesia (ALI). Arah Pengembangan Teknologi Logistik. Materi Seminar. Jakarta, 2010.

C.K. Prahalad, G. Hamel. (1994). Strategic management journal. Wiley Online Library.

Dinda, Sanya. (2020). Tiki Cetak Pertumbuhan 15\%, Industri Logistik Bangkit 2021.https://investor.id///business/industri-logistik-bangkit-2021.

Fauzan, Jayanti. (2015). Strategi Pemasaran Untuk Meningkatkan Volume Penjualan Dengan Menggunakan Blue Ocean Strategy Model Pada Usaha Sanjai Nitta Bukittinggi.

Garry, Hamel, C.K. Prahalad. (1994). Strategy As A Field Of Study: Why Search For A New Paradigm ? Prahalad, C. K., \& Hamel, G. (2007). Strategy as a field of study: Why search for a new paradigm? Strategic Management Journal, 15(S2), 5-16.

Hamijaya, Indriyani. (2014). Perumusan Blue Ocean Strategy Sebagai Strategi Bersaing Pada Perusahaan Keluarga Pt. Belirang Kalisari. https://www.mordorintelligence.com/industryreports/indonesia-freight-logistics-market-study.

Kim, Changsu Yang, Kyung Hoon Kim, Jaekyung. (2008). A strategy for third-party logistics systems: A case analysis using the blue ocean strategy

Kim, W.C., Mauborgne, R. (2017), Blue Ocean Shift (Indonesian Edition: Pergeseran Samudra Biru). Indonesia, Gramedia Pustaka Utama.

Melinda, Sarah, A., Abdillah, Yusri. (2018). Penerapan Blue.Ocean Strategy (Bos)Dalam Usaha Memasuki Pasar Internasional (Studi pada UMKM Pricilla Jilbab Bolak Balik).

Prita Suci Nurcandrani, Ade Tuti Turistiati, Sefy Andhriany, Dinda Intan Nurulina. (2020). Blue Ocean Strategy (BOS) Public Relations of Kampung Wisata Baluwarti Surakarta in Developing Village Branding.

Sadiq, Saba Amjad, Muhammad Saad Rafique, Muhammad Zeeshan Hussain, Shafqat Yasmeen, Uzma Khan, Mohammad Aamir. (2021). An integrated framework for lean manufacturing in relation with blue ocean manufacturing - A case study.

Utaminingsih, I.A. (2011). Rancangan Strategi Samudra Biru PT. SILKARGO Indonesia, Journal of Management and Business Review,8(1), pp. 15-33

Utaminingsih, Ina Astari. (2017). Rancangan Strategi Samudera Biru Pt. Silkargo Indonesia Samudera Indonesia Group (2010 - 2014) 